\title{
Development of Agrotourism in Kampung Kopi Amadanom, Malang
}

\author{
Edriana Pangestuti*, Latifah Hanum, Lestari Eko Wahyudi \\ Faculty of Administrative Sciences, University of Brawijaya, Malang, Indonesia
}

\begin{abstract}
Agrotourism is the community-based tourism activities that utilize the agricultural business as a tourist attraction that has many positive impacts which can improve the economy of society, especially in the form of society's income, open employment opportunities and business opportunities (entrepreneurship). This research aim was to develop the concept of agrotourism in the largest coffee producing area in Malang Regency that is in Amstirdam (Ampelgading, Sumbermanjing Wetan, Tirtoyudo, and Dampit). This study used a qualitative approach by observing the four areas to see the potential of each region. SWOT technique was used to analyze data and the results showed that Dampit is one area that has more potential attractions than other regions. One area in Dampit that has the potential to be developed into agro tourism is Kampung Kopi Amadanom. The results of this research indicated that the effort for developing Kampung Kopi Amadanom was still not maximal due to the lack of local government support and also lack of quality supporting resources. This research suggested by using a development model and applying appropriate strategy, it could provide and increase benefits not only for Kampung Kopi Amadanom but also for Malang generally.
\end{abstract}

Keywords: Agro-tourism, Amadanom, Coffee Agro-tourism, Tourism.

\section{INTRODUCTION}

Coffee is one of the significant commodities among the rural community in Indonesia. In Indonesia, the production of coffee beans in the past ten years increase significantly [1]. Coffee grains produced from Coffee plant, botanically belong to the Rubiacea. They're numerous Coffee species, which are cultivated in Indonesia, namely Coffea arabica, Coffea canephora (var. Robusta), Coffea liberica and Coffea exelsa. Two species, namely Coffea arabica and Coffea canephora var. Robusta widely planted in many parts of the Indonesia archipelago. Diverse environments and soils of Indonesia influence coffee plant grow and bean production. These are called specialty coffee. There are numerous specialty coffees, including Kintamani, Lanang, Toraja, and Wamena [2].

Malang Regency is one of the centers of coffee grains production, in which a wide area of coffee plantation exists and still maintained by the local community in many villages. In Malang, coffee is grown and distributed at the area of Ampelgading, Tirtoyudo, and Dampit area, or known as Kopi Amstirdam. In the past, this coffee was very famous among European and received positive appreciation among the coffee lover in Europe. More than $90 \%$ of coffee that cultivated and produced from Dampit area was exported to numerous countries, including European

\footnotetext{
* Correspondence address:

Edriana Pangestuti

Email : edriana_fia@ub.ac.id

Address : Faculty of Administrative Sciences, Mayjen Haryono No 164,65145 , Malang.
}

countries and Japan. Coffee is important among local community in Dampit, especially its role in local economic development [3]. Future economic development based on coffee crops can be initiated by promoting agrotourism .

Scholar points out that the development of agrotourism by involving culture and local wisdom in farming and land management are able to increase local economic earnings [4]. These practices especially important to promote local wisdom and traditional knowledge of many communities in developing countries. The development of coffee-based agrotourism will increase the economic earning of the coffee farmer and the local community in Dampit [5]. Moreover, developing agrotourism also important to educate the visitor about coffee cultivation and production. Thus it can be concluded that the aims of this study were not only to develop the concept of agrotourism but also to increase the standard of living of community $[5,6]$.

\section{METHODS}

The research was done following a qualitative approach [7]. The functions of SWOT analysis are to get information from the situation analysis and describe the internal (strengths and weaknesses) and external (opportunities and threats) factors that determine the strategy [7]. The first step was collecting data by surveys or observations technique on four areas which are Ampelgading, Sumbermanjing Wetan, Tirtoyudo, and Dampit. Furthermore, we analyzed the potential of tourism in each region according to the topic of research. From the numerous criteria 
that stated in this study, Dampit Sub-regency selected as an observation site, and the Amadanom Village has selected as a focus of the study. The results of pre-research indicated that Amadanom Village has potential and can be developed as agrotourism. The Amadanom location is strategic that is located on Highway of Malang-Lumajang, making this tourist attraction is easy in terms of accessibility.

\section{RESULTS AND DISCUSSION}

Amadanom is one of the centers of coffee production in Dampit. Recently, there are some efforts of agricultural diversification through the idea to develop coffee-based agrotourism [8]. Recently, the initial community group to handle and manage tourism potentiality in the village has been established, with the coffee farmer community group (locally called Kelompok Tani or Poktan) as the main actor in tourism development. Amadanom Village has five farmer community groups, including Harapan, Makmur 74, Trisno Manunggal, Sinar Tani and Barokah Ahmadi. The results of pre-research showed that among the five farmer groups, community group Harapan is the most active group (farmers) in cultivating coffee and making coffee as a new tourist attraction in the form of agrotourism [9].

Poktan Harapan has a main goal, which is to improve the welfare of all coffee farmers and avoids conflicts among coffee farmers, especially in Amadanom. Besides that, it also served to provide information related to the cultivation, processing, and distribution of coffee by holding the training monthly. The training was attended by almost 20 participants who were all heads of each farmer group. Each trainee was expected to apply the knowledge they gain to increase and develop their farm [1]. Unfortunately, the training only focuses on cultivating seeds and improving the quality of coffee crops. There had been no training related to the development of the coffee plantations as a place for tourism.

Field research found that human resources are still poor in tourism resources management. The potential value of numerous resources for agrotourism development in the village is poorly understood. The community in Amadanom Village through Poktan Harapan has been declared their village as Amadanom coffee farm ecotourism. However, the implementation of ecotourism has been rarely understood and practiced. The name uses the word ecotourism, but there are no ecotourism practices in the activities. The community group of Poktan
Harapan has poor knowledge about tourism and seems to be lack of philosophy of ecotourism especially agrotourism. Poktan Harapan has coffee farmer member with its own lands, but they unable to integrate farming activity (i.e. seedling, planting, maintaining and harvesting) into agro-tourism.

\section{Ecotourism implementation}

Recently, ecotourism has been promoted as ideal tourism activity to promote environmental conservation, local economic development, and local culture promotion [10]. Scholar points out that there are important aspects should be meet by ecotourism, including education, nature conservation, and increase local economy grows [11]. Ecotourism is the form of sustainable tourism [12]. Following such principles, some findings were described below:

\section{Education}

Field observation confirms that there are no education aspects in ecotourism program in Amadanom coffee farm. There is a wide area of coffee field and coffee processing activity, but there is no tourist guide available to explain the coffee and its processing [11]. It leads to the tourist's poor knowledge of coffee. Whereas the tourists' understanding of the coffee plant is very important. Tourists can learn how to cultivate a coffee plant, know the varieties of coffee plants, and understand the coffee processing into a product that is ready for consumption.

\section{Nature conservation}

Agrotourism coffee processing is expected to preserve the coffee garden by practicing various techniques appropriate in cultivating coffee. In the development of tourist and visitor infrastructure, they also used local material. The controversial aspect in infrastructure development, however, related to the establishment of the permanent toilet and praying room in the central position in the coffee garden by local government. This lead to the decreasing quality of scenic beauty of coffee garden landscapes [8].

\section{Increase of community economic status}

The ecotourism in Amadanom has been believed able to increase economic earning of the local family who joins the ecotourism program $[10,13]$. The farmer stated that direct selling to tourist through agro-tourism mechanism has a positive impact on the economic earning. It is because of the 
received price is higher than paid price by the coffee factory in Dampit. Ecotourism program is able to increase revenue from coffee.

\section{Sustainability}

The implementation of ecotourism in the coffee farm in Amadanom was less sustainably. One of the reasons for this situation is because tourism is still at the beginning of development. There are, however, high spirits for tourism development among Poktan member and village officer of Amadanom. They have the spirit to develop rural tourism in Amadanom based on coffee. The high enthusiasm is the important aspect for future tourism development in Amadanom.

SWOT Analysis on the Development of Kampung Kopi Amadanom

\section{Strengths}

Coffee from Indonesia has been internationally recognized. This is shown by 4C (Common Code for the Coffe Comunity) certificate achievement by Indonesia coffee. One of the famous coffees from Indonesia was origin from Dampit, Malang Regency in East Java. About $90 \%$ of coffee from Dampit, the majority is Robusta, has been exported to numerous countries [3]. In Dampit, Coffea canephora (var. Robusta) was cultivated at the area with elevation $800 \mathrm{mdpl}$, with suitable temperature and proper crops management. Harvesting and the postharvesting process was done traditionally, and therefore it is environmentally sustainable.

In Amadanom, tourism-based coffee has been introduced and initiated as one of the diversification of coffee crops. Recently, there are new tourism object in the coffee garden. Groups of farmer develop café in coffee orchards environment. Located at the side of provincial road Lumajang-Malang, the café was easy to find and has high accessibility from the visitor. In this Cafe, the visitor can enjoy Dampit's coffee in coffee orchards. There are some facility has been established to increase visitor satisfaction. Local movement and private sector have supported the development of the facility. The toiled and room for praying was provided by local government, and the visitor gazebo was provided by PT Krebet Baru.

\section{Weakness}

The farmer group (Poktan) is the pioneer and recently is the main actor in coffee agrotourism in Amadanom. Among numerous farmer groups, only one group Poktan Tani Harapan - which actively promote and implement agrotourism in coffee orchards area. The problems are related to the low capacity of human resources. Not all community members in Amadanom and people who actively involved in tourism program in Amadanom aware about the potentiality of tourism to generate alternative economic revenue.

There is still improvement needed in the development of ecotourism in Amadanom coffee area. It is including increasing community understanding in tourism service, tourism planning, and tourism program development. The community with tourism awareness is the community with good understanding and awareness about tourism, and able to actively participate in tourism development and provide good service to the visitor who visits the recreation area [14].

As far, the marketing effort of coffee farm owner was not optimal. Amadanom has social media (i.e. Instagram), but it seems not effective to promote Amadanom. Social media as an electronic word of mouth that is significant to use in order to increase the existence of coffee-based agrotourism in Dampit [15].

\section{Opportunity}

The opportunity for the development of Coffee agrotourism in Amadanom came from the tourists who visit nature-based tourism attraction in Banyu Anjlok tourism. The location of Amadanom located between Banyu Anjlok and Malang, and tourist from Malang potentially visit Amadanom as coffee-based agrotourism destination. The Dampit coffee also received positive appreciation from consumer and has been known as one of the best coffee in Indonesia. The agrotourism coffee management can receive income from the visitor who visit Amadanom, buy and order coffee for them and their family.

\section{Threat}

Dampit sub-regency has a wide area of the coffee plantation, and the idea to 
diversify coffee orchards as the tourist attraction to increase economic revenue can be copied by other sub regency or village. This can be a competitor for coffee agrotourism in Amadanom.

SWOT Analysis on the development of Kampung Kopi Amadanomlt can be seen from table 1 and 2 as follow. The tables showed that Kampung Kopi Amadanom has the strength score of 3.5 while the weakness showed the score -2.8 . Thus the accumulated value of this internal factor is 0.7 ; this value formulate that the strategy must utilize the strength and minimize the weakness.

Table 1. The Internal Factor at Kampung Kopi Amadanom

\begin{tabular}{|c|c|c|c|c|c|}
\hline \multirow{2}{*}{ No } & \multirow{2}{*}{ Internal Factor } & \multicolumn{4}{|c|}{ Scoring } \\
\hline & & Weight & Rating & Score & $\Sigma$ \\
\hline & STRENGTH & & & & \\
\hline 1 & $\begin{array}{l}\text { Amadanom is the largest } \\
\text { coffee producer in East } \\
\text { Java }\end{array}$ & 0.5 & 3 & 1.5 & \\
\hline 2 & $\begin{array}{l}\text { Amadanom is one of the } \\
\text { regions which have } \\
\text { coffee attraction }\end{array}$ & 0.3 & 4 & 1.2 & \\
\hline \multirow[t]{3}{*}{3} & $\begin{array}{l}\text { There were a lot of } \\
\text { potential labor }\end{array}$ & 0.2 & 4 & 0.8 & 3.5 \\
\hline & Sub score & 1 & & & \\
\hline & WEAKNESSES & & & & \\
\hline 1 & $\begin{array}{l}\text { Lack of supporting } \\
\text { facilities and } \\
\text { infrastructure }\end{array}$ & 0.5 & -3 & -1.5 & \\
\hline 2 & $\begin{array}{l}\text { The arrangement of the } \\
\text { area was not interesting }\end{array}$ & 0.3 & -3 & -0.9 & \\
\hline \multirow[t]{3}{*}{3} & Lack of human resources & 0.2 & -2 & -0.4 & -2.8 \\
\hline & Sub score & 1 & & & \\
\hline & TOTAL SCORE & & & & 0.7 \\
\hline
\end{tabular}

Table 2. External Factor at Kampung Kopi Amadanom

\begin{tabular}{lllll}
\hline \multirow{2}{*}{ No } & \multicolumn{4}{c}{ Scoring } \\
\cline { 2 - 5 } & Weight Rating & Score & $\boldsymbol{\Sigma}$ \\
\hline $\begin{array}{l}\text { OPPORTUNITIES } \\
1\end{array}$ & 0.6 & 4 & 2.4 & \\
$\begin{array}{l}\text { Supported from the } \\
\text { government for Amadanom }\end{array}$ & & & & $\mathbf{3 . 2}$ \\
$2 \begin{array}{l}\text { One of the tourist place that } \\
\text { offers ecotourism concept }\end{array}$ & 0.4 & 2 & 0.8 & \\
\hline$\quad$ Sub score & $\mathbf{1}$ & & & \\
\hline $\begin{array}{l}\text { THREATS } \\
1\end{array}$ & 0.5 & -2 & -1.0 & \\
$\begin{array}{l}\text { Environmental issues about } \\
\text { tourist areas }\end{array}$ & 0.5 & -3 & -1.5 & $\mathbf{- 2 . 5}$ \\
$\begin{array}{l}\text { The condition of areas have } \\
\text { the potential of erosion }\end{array}$ & 0 & $\mathbf{1}$ & & \\
\hline Sub score & & & $\mathbf{0 . 7}$ \\
\hline TOTAL SCORE
\end{tabular}

Table 2 showed that the value of the opportunity was 3.2 and the threat score was at the value of -2.5 . The external factor obtained an accumulation of 0.7 . This may indicate that Amadanom has to take advantage of existing opportunities and minimize threats. Thus, the accumulation value of SWOT matrix analysis result was $(0.7 ; 0.7)$, it showed that the condition of agrotourism of Amadanom in the position of quadrant $\mathrm{I}$, as shown in Figure 1.

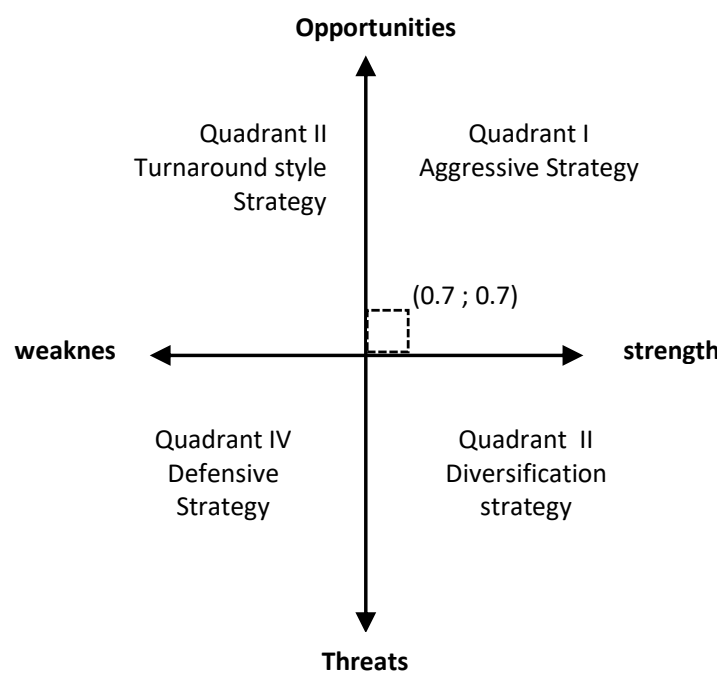

Figure 1. SWOT Result

\section{Development Strategy of Amadanom}

Strategies that need to be undertaken to support Amadanom as agrotourism village by the considerations of strengths and opportunities on resources, among others, as presented in Table 3. The strategy that recommended to improve the agrotourism in Amadanom was SO strategy (Strength and Opportunities). In this strategy, Amadanom should do promotion [14]. Promotion is one of the most important elements which include several action plans to inform the current or prospective customers about the development of a good product, its price, and availability [16]. By using promotion, encourage the actual and potential customers to travel a destination (agrotourism) through the spreading of information could be reached $[12,14,15]$.

The development of technology such as online or digital marketing system can be used to promote Amadanom as interesting destination $[17,18]$. Furthermore, Amadanom should hold an activity such training program to all managers to increase and develop their human resources capability [1]. Training is the process that provides employees with the knowledge and the skills required to operate within the systems and standards set by management [11]. 
Table 3. The Development Startegies for Amadanom as Agrotourism Matrix

\begin{tabular}{|c|c|c|}
\hline $\begin{array}{ll}\text { EFAS } & \text { IFAS } \\
\end{array}$ & STRENGTHS & WEAKNESSES \\
\hline & $\begin{array}{l}\text { a. Amadanom is the largest coffee producer } \\
\text { in East Java. } \\
\text { b. One area that has the coffee agro Tourism } \\
\text { concept } \\
\text { c. Have a number potential human resources }\end{array}$ & $\begin{array}{l}\text { a. Supporting facilities and infrastructure } \\
\text { are still limited } \\
\text { b. The location design uninteresting } \\
\text { c. Its human resources are unskilled }\end{array}$ \\
\hline $\begin{array}{l}\text { OPPORTUNITIES } \\
\text { a. There is government support related } \\
\text { to the development of Amadanom as } \\
\text { agrotourism } \\
\text { b. The only tourist place that offers the } \\
\text { concept of agro-tourism }\end{array}$ & $\begin{array}{l}\text { Strategy SO } \\
\text { a. Do promotion } \\
\text { b. Training to all managers } \\
\text { c. Spatial planning and arrangement }\end{array}$ & $\begin{array}{l}\text { Strategy WO } \\
\text { a. Increase the attractions } \\
\text { b. Increasing the number of tourism } \\
\text { facilities and infrastructure }\end{array}$ \\
\hline $\begin{array}{l}\text { THREATS } \\
\text { a. Environmental issues } \\
\text { b. The potential for erosion / landslide }\end{array}$ & $\begin{array}{l}\text { Strategy ST } \\
\text { a. Establish a monitoring and evaluation } \\
\text { system by involving communities and } \\
\text { stakeholders } \\
\text { b. Rehabilitate the ecosystem of tourist areas }\end{array}$ & $\begin{array}{l}\text { Strategy WT } \\
\text { a. Conduct training on nature conservation } \\
\text { b. Provide an understanding of agro- } \\
\text { tourism } \\
\text { c. Location setting }\end{array}$ \\
\hline
\end{tabular}

\section{CONCLUSION}

SWOT analysis indicated a framework for helping the planners to identify the strategies of achieving goals. The SWOT analysis is expected to provide information related to the strengths, obstacles, challenges, and efforts that must be anticipated and undertaken to manage the Amstirdam Coffee Village in order to attract and increase the number of tourist arrivals.

Kampung Kopi Amadanom has been aplying the concept of agrotourism since 2016 by introducing the natural potential in terms of coffee farming also provides education about coffee processing for tourists. Poktan Harapan developed the concept. However, the development and management were still low. This is due to lack of information and knowledge about tourism, especially agro-tourism. The finding shown that the appropriate strategies that should have been done were aggressive strategy by 1) doing aggressive promotion, 2) training to all managers and 3) spatial planning and arrangement. Adopting implementing Internet technology was the best and useful result to make Amadanom better known by the visitors.

Internet nowadays became apart from channel to collect information, offer enterprises the opportunity to market goods and services to more customer than ever before. Moreover, Amadanom has to increase their human resources capability. Training for all managers could be useful to improve their knowledge and solve the problem at Amadanom. The effective training and development programs for employees can help and resolve conflicts within an organization. And the last important factor that useful was spatial planning and arrangement.

\section{REFERENCES}

[1] Abdullah, H. 2017. Peran manajemen sumber daya manusia dalam organisasi. Jurnal Warta 51.

[2] Alfansi, L. 2012. Pemasaran jasa finansial. Salemba Empat. Jakarta.

[3] Malangtimes. 2017. Kuatkan petani kopi Amstirdam, Dinas Pertanian dan BI latih dan serahkan alat pengolahan kopi. Available at: https://www.malangtimes. com/baca/22661/20171121/232447/kuatk an-petani-kopi-amstirdam-dinas-pertaniandan-bi-latih-dan-serahkan-alat-pengolahankopi/

[4] Rangkuti, F. 2006. Analisis SWOT teknik membedah kasus bisnis. PT. Gramedia Pustaka Utama. Jakarta.

[5] Sunaryo, B. 2013. Kebijakan Pembangunan destinasi pariwisata konsep dan aplikasinya di Indonesia. Gava Media. Yogyakarta.

[6] Suansri, P. 2003. Comunity based tourism handbook. Responsible Ecological Social Tours (REST) Project. Bangkok, Thailand.

[7] Arikunto, S. 2006. Prosedur penelitian: suatu pendekatan praktek. Rineka Cipta. Jakarta.

[8] Ministry of Tourism. 2016. Panduan pembentukan desa wisata. Ministry of Tourism, Republic of Indonesia. Jakarta.

[9] Pamulardi, B. 2006. Pengembangan agrowisata berwawasan lingkungan. Master Thesis. Diponegoro University. Semarang.

[10] Mowforth, M. and I. Munt. 1988. Tourism and sustainability: New Tourism in the Third World. London. Routledge. 
[11] Kerry, L. Sommerville 2007. Hospitality employee management and supervision, concepts and practical applications. John Wiley \& Sons. New Jersey.

[12] Baldemoro, J. 2013. Tourism promotion. Slide share. Available at: http://www.slideshare.net/JHBlue/tourismpromotion-28432196.

[13] Nelson, H. 1993. Tourism and sustainable development. University of Waterloo Press. Harlow.

[14] David, F. 2006. Manajemen strategis, $10^{\text {th }}$ Ed. Salemba Empat. Jakarta.

[15] Kotler, P. 2000. Marketing management: Millennium Ed, International Ed. Prentice Hall. International, Inc. new jersey.

[16] Fandeli, C. 2001. Dasar-dasar manajemen kepariwisataan alam. Liberty Offset. Yogyakarta.

[17] Griffin, M. 2000. E-marketing planning: accountability and E-metrics. Embelix Software. Available at: http://www.templatezone.com/pdfs/ems_ whitepaper.pdf.

[18] Keegen, W. J. and M. C. Green. 2008. Global marketing, $5^{\text {th }}$ Ed. Pearson Education. London. 